\title{
The Effects of Intellectual Capital on Financial Performance and Market Value: Evidence from Turkey
}

\author{
Ilker YILMAZ ${ }^{*}$, Goksel ACAR ${ }^{* *}$
}

Received: March 28, 2018

Revised: May 11, 2018

Accepted: May 15, 2018.

\begin{abstract}
In this study we aim to examine the effects of intellectual capital and its components on companies' market value and financial performance in Turkey. The financial and market data of production companies listed in Borsa Istanbul 100 index (BIST-100) for the periods 2011 through 2014 are used as dataset. We selected three different measures for financial performance; ROA, ROE and Net Profit Margin, and one measure for market value; Market to Book Ratio. As independent variables, we firstly took Modified Value Added Coefficient (M-VAIC), secondly we took three components of M-VAIC. Besides, we added natural logarithm of assets to control for variation in asset size of companies and tested its significance. The results suggest multi factor models are more powerful than single factor model in explaining the market performance and financial performance. The paper also reveals that models explaining financial performance provide more accurate results than the models of market performance. The analysis also exposes that physical capital and human capital has a significant effect on financial performance whereas physical capital and relational capital has an influence on market performance.
\end{abstract}

Keywords: Intellectual capital, performance, M-VAIC, Market value, Turkey.

JEL Code Classification: O34, L25, G32

UDC: 330.322

DOI: https://doi.org/10.17015/ejbe.2018.021.07

\footnotetext{
* Assistant Professor, Dhofar University, Oman, E-mail: iyilmaz@du.edu.om

*** Assistant Professor, Dhofar University, Oman, E-mail: gacar@du.edu.om 


\section{Introduction}

It has been always questioned and discussed that why a company's market value is different than its book value. Due to several factors, the value priced at stock exchanges might be even ten times higher than the value reported on historical balance sheets. Academicians and practitioners searched for the possible sources of this value difference. Although the balance sheet mirrors the company's financial position as of a specific date, historical cost principle of accounting does not allow. Fair value accounting helps close the gap to some degree, however by its nature; balance sheet is a static financial statement. From the valuation viewpoint, the company value is the present value of free cash flows expected in the future. It is an implicit assumption that the cash flows are generated by the exploiting the assets, both tangibles and intangibles. The question arises at this point; are there any other sources of value which are invisible and not reported on the balance sheet. Intellectual capital comprises those invisible factors.

Intellectual capital is difficult to measure; however, some methods were developed. The most famous of those methods is Value Added Intellectual Capital $\left(\right.$ VAIC $^{\mathrm{TM}}$ ). Many studies used VAIC ${ }^{\mathrm{TM}}$ as a measure of Intellectual Capital, however in recent years; there have been also many criticisms against it. New versions were developed to overcome the drawbacks of VAIC ${ }^{\mathrm{TM}}$. Modified Value Added Intellectual Capital (M-VAIC) which was constructed by Ulum et al. (2014) is a widely recognized methodology. In this study, we also use M-VAIC.

We examine the effects of intellectual capital on company's market value and profitability by using Turkish data. There are several studies in this field for both developed and developing countries. Turkey is an emerging market; therefore, the paper makes a contribution for emerging markets research. In today's competitive environment, to increase financial performance and market value, companies must invest in their intellectual capital. The article emphasizes the importance of intellectual capital and aims to find out its role in improving a company's financial performance and in increasing its market value. It has important practical implications not only for financial executives but for all managers as well, because components of intellectual capital are closely related to all parts of an organization. The article uses a sample composed of production companies and performs panel data analyses covering 4 years and aims to explain both the effects of M-VAIC and its components on financial performance and market value. Additionally, we added natural logarithm of assets as a variable to control the variance resulting from different asset sizes of companies and tested its significance.

The remainder of the paper is organized as follows; the next section provides a brief review of the literature about intellectual capital and its impact on market value and profitability. The third section focuses on measurement of intellectual capital. The latter section explains methodology and data. The fifth section discusses analyses and the results. The last section makes conclusions. 


\section{Review of Literature}

Intellectual capital is an elusive concept, it is difficult to measure in monetary units, it is difficult to define and describe. There are several definitions presented up to now, but there exists no consensus and no unique, agreed-upon definition. Intellectual capital is the intellectual material which undergoes a process whose aim is to produce a higher value asset and during this process, the raw material of the process (intellectual material) is to be formalized, captured and leveraged (Klein \& Prusak, 1994).

Intellectual capital is composed of intellectual material; information, knowledge, intellectual property, experience and relationships, all of which are to be used to make a company more successful (Stewart, 1997). The main characteristic of intellectual capital is the fact that it represents the hidden values of the company (Edvinsson, 1997). In other words, it is the gap between market value and book value (Edvinsson \& Malone, 1997). In the literature, it is commonly accepted that intellectual capital is composed of three categories; human capital, structural capital and relational capital (Bontis, 1999; Edvinsson \& Malone, 1997; Sveiby, 1997; Roos et al., 1997). Intellectual capital can be measured as the sum of values in these three categories.

Human capital consists of knowledge and skills owned by employees, structural capital consists of organizational structure and databases, and customer capital consists of relationships with both customers and suppliers (Bornemann et al., 1999). Sheer intelligence of the organizational members is the core of human capital and it is important since it functions as the source of innovation and strategic renewal (Bontis, 1998). Human capital can also be defined as the implicit knowledge assets of the employees and it affects the work performance of the company. To create organizational value, it is important to convert this implicit knowledge into an explicit knowledge throughout the organization (Bozbura, 2004).

Human capital consists of the factors which make workforce value-adding, including training and competence (Edvinsson \& Malone, 1997), intellectual agility and skills (Roos et al., 1997), collective knowledge, creativity and innovativeness of employees (Zambon, 2002).

Belkaoui (2003) defines structural capital as organizational knowledge in terms of technologies, inventions, data, publications, strategy/culture, structures/systems, organizational routines and procedures. It covers and represents the effectiveness of the policies and processes, the positive nature of the working environment, and the innovation produced by R\&D (Guthrie \& Petty, 2000). Roos et al. (1997) claims that structural capital is "what remains in the company when employees go home for the night" and states that its certain elements can be legally protected in the form of patents and trademarks. 
Third dimension of intellectual capital is relational capital, although it has been called as customer capital in some studies, relational capital is a better concept because it consists of all relationships with the stakeholders. Bontis (1999) describes the knowledge of market channels, relationships with customers and suppliers and a sound understanding of government and industry association impacts as the main theme.

Bontis et al. (2000) examined the interrelationships among components of intellectual capital and the relationship with business performance by using a questionnaire in Malaysia. They grouped the companies in the sample as service and non-service. As for the relationship with business performance, they found significant results for both groups, but in service industries, it is more substantive. They concluded that development of structural capital provides a competitive advantage which results in an improved business performance. Belkaoui (2003) tested the relationship between intellectual capital and company performance by using the data of 81 US multinational companies and found positive and significant results. As the measure of company performance, net value added was used and it was concluded that net value added is a relevant measure of wealth creation; intangibles and especially intellectual capital can function as a sustainable source of this wealth creation.

Firer and Williams (2003) investigated the association between intellectual capital and traditional performance measures; profitability, productivity and market value by using the data of 75 South African companies. They employed Value Added Intellectual Coefficient (VAIC ${ }^{\mathrm{TM}}$ ) and called the independent variable as the efficiency of value added (VA) which is composed of physical, human and structural capital. The relationships between efficiency of VA and performance measures are limited and mixed. With regard to profitability, they found only a moderately positive relationship with structural capital. As for productivity, findings suggest a negative significant association with human capital and there exists a trade-off between physical and human capital. With respect to market valuation, more importance is attached to physical capital than the other two components, human and structural capital.

Lehtimaki and Lehtimaki (2016) analyzed the impact of knowledge capital, which can be divided into two parts as individual and organizational capital, on the firm performance by using the data of 500 largest firms in Finland for the period of 2005-2008. They found that the changes in both individual and organizational capital have significant effects on performance. The results of the study had implications for the firm, suggest investing in organizational capital for short-run growth, whereas invest in individual capital for long-run growth.

Chen et al. (2005) examined the relationship between value creation efficiency and market value and financial performance by using the data of Taiwanese listed companies. Based on VAIC ${ }^{T M}$ measures, they looked for relationships with both 
current and future performance and market valuation indicators and they found positive associations.

Yalama and Coskun (2007) measured the intellectual capital performance of quoted banks at Istanbul Stock Exchange for the period of 1995-2004 by using $\mathrm{VAIC}^{\mathrm{TM}}$ and they tested its effect on profitability by using Data Envelopment Analysis. They constructed three portfolios which use intangible asset effect, tangible asset effect and financial effect as inputs, respectively. As output values, they used different profitability ratios. They calculated a ratio of transforming intellectual capital into profitability and the value of this ratio for the sample was $61.3 \%$ on average. Among three portfolios, the one which uses intellectual capital as input measure yields the highest returns.

Sharabati et al. (2010) searched for the relationship between intellectual capital and business performance in the pharmaceutical industry by conducting a survey of 132 top and middle-level managers. They found a strong, positive relationship and concluded that the companies in the sample manage intellectual capital effectively and this contributes their performance positively. Maditinos et al. (2010) mention about the four elements of intellectual capital as human, customer, structural and innovation capital and they tested the inter-relationships among the elements and the relationship with business performance. They applied a psychometrically validated questionnaire to the sample composed of companies from Athens Stock Exchange and grouped as service and non-service. They found that human capital has a positive relationship with customer and structural capital for both service and non-service industries. There is a lower level of positive relationship between customer and structural capital in service industries. They found a strong positive relationship between innovation capital and structural capital. Their final hypothesis proved a positive relationship between structural capital and business performance; however, this relationship is more substantive in non-service industries.

Ozkan et al. (2017) analyzed the intellectual capital-financial performance relationship by using 44 Turkish banks for the period 2005-2014. Measuring intellectual capital through M-VAIC methodology and using ROA as the indicator of financial performance, they found a positive relationship. Human capital efficiency has more effect on intellectual capital than other components, however capital employed efficiency is more influential on financial performance.

\section{Intellectual Capital and Its Measurement}

Although several attempts have been made to measure companies' intellectual capital, still there is not solidarity for the method of measurement. Pulic (2000) developed VAIC ${ }^{\text {TM }}$ which measures the efficiency of value added by corporate intellectual ability and this coefficient has been commonly accepted and applied in both academic studies and in business practices. It has three components: physical capital, human capital, and structural capital. While VAIC ${ }^{T M}$ has been used in many 
studies about different countries, it is also criticized and modified versions are proposed. We firstly present the original VAIC $^{\mathrm{TM}}$ model and then examine M-VAIC model.

$$
\text { VAIC }{ }^{T M} \text { and } M-V A I C
$$

The most important advantage of $\mathrm{VAIC}^{\mathrm{TM}}$ is that it can be calculated by using publicly available and audited financial statements and therefore it is an objective measure. In addition, it is very simple and easy to calculate. On the other hand, $V_{A I C}{ }^{T M}$ is criticized in that its structural capital component is not complete. Due to the VAIC ${ }^{\mathrm{TM}}$, $s$ value added calculation which is formulated as the company's output, and also due to the fact that R\&D and advertising expenditures are expensed, not capitalized according to conservative accounting principles, those expenses are deducted, and therefore it underestimates value added (Chen, et al., 2005). VAIC ${ }^{\text {TM }}$ is composed of three components:

VACA: Capital Employed Efficiency; (VA / CE)

VAHU: Human Capital Efficiency; (VA / HU)

STVA: Structural Capital Efficiency; (SC / VA)

$V A I C^{T M}=V A C A+V A H U+S T V A$

The formulas of VAIC ${ }^{\text {TM }}$ components are based on Value Added (VA) which is measured as the difference between output and input. By using financial statement items, it can be expressed as the difference between sales and cost of goods sold. Based on the VA, the components are formulated as follows:

where CE is capital employed and calculated as total assets minus intangible assets;

$\mathrm{HU}$ is human capital and calculated as personnel expenses;

SC is structural capital and calculated as VA- HU.

VACA represents the amount of value added (VA) for each unit of capital employed; VAHU represents the amount of VA for each unit of human capital (HU) which is expressed as employee salaries. On the other hand, structural capital coefficient (STVA) is derived differently. The relationship among VA, HU, and SC may cause multicollinearity problem because they have a linear relationship as VA is assumed as the sum of HU and SC. To overcome this problem SC is divided to VA. Zeghal and Maaloul (2010) stated that this rate shows the percentage of SC in creating VA.

Although VAIC ${ }^{\mathrm{TM}}$ model has some advantages, it has also been criticized due to some reasons. Stahle et al. (2011) claimed that VAIC ${ }^{\text {TM }}$ can be an indicator of labor and capital investment efficiency, but it has no relation with intellectual capital. They argue against the model because of using overlapping variables. They also found that VAIC ${ }^{\mathrm{TM}}$ has no correlation with market values of companies. They asserted two reasons for this situation; firstly, there is a confusion regarding 
capitalized items and secondly cash flow items used and intellectual capital concepts are mostly misused.

lazzolino and Laise (2013) criticizes VAIC ${ }^{\mathrm{TM}}$ model due to the misperception in the meanings of terms such as structural capital (SC) and human capital (HC). They also claimed that VAIC ${ }^{T M}$ is not an alternative to other performance measurement tools, such as Economic Value Added (EVA), instead it measures a different aspect of performance, and therefore it can be a complementary part of performance measurement together with other traditional methods.

Several authors attempted to improve and modify VAIC ${ }^{T M}$ model. Nazari and Herremans (2007) modified the original model by analyzing the interrelationships among the components of IC and tested several hypotheses about the associations of the components. They called this model as extended VAIC model. In addition to the components of the original model, they attempted to break down the existing components and add new concepts, so they introduced the concepts of process capital, renewal capital, customer capital and innovation capital.

Ulum et al. (2014) also modified the $\mathrm{VAIC}^{\mathrm{TM}}$ model by adding relational capital which is measured by marketing costs and applied this modified VAIC (M-VAIC) in Indonesian banking sector. They concluded that M-VAIC is an effective tool to measure intellectual capital performance of banks. Ulum et al. (2017) examined the intellectual capital-financial performance relationship by applying M-VAIC model to 50 biggest companies according to market capitalization in the Indonesian stock exchange for the period of 2007-2014 and concluded that M-VAIC affects positively current and future financial performance and intellectual capital has an important role in corporate value creation.

Nimtrakoon (2015) added "relational capital efficiency" component to VAIC model, called this model as modified VAIC (M-VAIC) and by using it, examined the relationship between intellectual capital and financial performance and market value. The sample is composed of 213 technology companies from stock exchanges of five ASEAN (Association of Southeast Asian Nations) countries. Results indicated that intellectual capital has positive associations with both market value and financial performance. Capital employed efficiency and human capital efficiency have a higher driving effect compared to structural and relational capital efficiency.

Ulum et al. (2014) suggest M-VAIC as more explanatory than traditional VAIC $^{\text {TM }}$ model. M-VAIC has one more variable which is called relational capital efficiency (RCVA). It is calculated as the division of relational capital (RC) to value added (VA). They identified and computed Relational Capital (RC) as marketing costs. For our data, we took RC as the total of marketing and advertising costs, because Turkish companies report advertising costs separately.

RCVA: Relational Capital (RC) / Value Added (VA)

RC: Marketing Costs + Advertising Costs. 


\section{Data and Methodology}

To test the effect of intellectual capital on a company's market value, Market to Book Ratio (M/B) is used as a measure of company's value and firstly we conducted a model with five independent variables. This model has four components of $M$ VAIC, namely; Capital Employed Efficiency (VACA), Human Capital Efficiency (VAHU), Structural Capital Efficiency (STVA), Relational Capital (RCVA), and as a control variable for size Natural Logarithm of Total Assets (LNTA). Secondly, the paper tried to find out how (M/B) is affected by a four-factor intellectual capital model which includes Capital Employed Efficiency (VACA), Human Capital Efficiency (VAHU), Structural Capital Efficiency (STVA) and Relational Capital (RCVA). Thirdly, a single variable model with Modified Value Added Intellectual Capital (M-VAIC) as independent variable is tested.

After testing the relation between intellectual capital and market performance, the same three models are used to estimate companies' financial performance. However, unique performance measure is not used as dependent variable. Instead, three different performance measures are used, including Return On Asset (ROA), Return On Equity (ROE), Net Profit Margin (NPM).

The sample includes 49 companies with the data for 4 years, from 2011 to 2014. These companies are production companies which are listed in BIST 100 index of Borsa Istanbul. We assume that, the difference in business practices and company characteristics are significant for production and non-production companies resulting in a difference in accounting records and financial report

As Nimtrakoon (2015) stated, companies with big sizes may have higher ratios compared to other companies. To achieve this, she took natural logarithm (In) of total assets because, taking the assets as a control variable would be somewhat problematic since, there can be huge differences among assets of companies and this would boost heteroscedasticity and may harm the significance of independent variables. Benefited from these findings, we added natural logarithm of assets as control variable to our model.

The paper employed Stata software in generating results. The data have both cross section and time dimensions and empirical work is based on panel data econometrics. The dataset has 49 companies which has considerably high cross sectional dimension, hence selected random effects model to eliminate the problem of lacking degree of freedom that can be caused by fixed effects model. Furthermore, Hausman specification test is applied to determine the best appropriate model, and the results were in support of random variables as well. Afterwards, the paper tested the availability of pooled regression model against random effect and random effect model provided more accurate results. We also performed for the existence of homoscedasticity and multicollinearity. The models are illustrated below. 
The models testing the relation between M/B ratio and intellectual capital are:

$$
\begin{aligned}
& M B_{i, j}=\beta_{0}+\beta_{1} \text { vaca }_{i, j}+\beta_{2} \text { vahu }_{i, j}+\beta_{3} \text { stva }_{i, j}+\beta_{4} \text { rcva }_{i, j}+\beta_{5} \operatorname{lnta}_{i, j}+\varepsilon_{i, j} \\
& M B_{i, j}=\beta_{0}+\beta_{1} \text { vaca }_{i, j}+\beta_{2} \text { vahu }_{i, j}+\beta_{3} \text { stva }_{i, j}+\beta_{4} r c v a_{i, j}+\varepsilon_{i, j} \\
& M B_{i, j}=\beta_{0}+\beta_{1} \text { mvaic }_{i, j}+\varepsilon_{i, j}
\end{aligned}
$$

The models testing the relation between ROA ratio and intellectual capital are:

$$
\begin{aligned}
& R O A_{i, j}=\beta_{0}+\beta_{1} v a c a_{i, j}+\beta_{2} v a h u_{i, j}+\beta_{3} s t v a_{i, j}+\beta_{4} r c v a_{i, j}+\beta_{5} \operatorname{lnta} a_{i, j}+\varepsilon_{i, j} \\
& R O A_{i, j}=\beta_{0}+\beta_{1} v a c a_{i, j}+\beta_{2} v a h u_{i, j}+\beta_{3} s t v a_{i, j}+\beta_{4} r c v a_{i, j}+\varepsilon_{i, j} \\
& R O A_{i, j}=\beta_{0}+\beta_{1} \text { mvaic }_{i, j}+\varepsilon_{i, j}
\end{aligned}
$$

The models testing the relation between ROE ratio and intellectual capital are:

$$
\begin{aligned}
& R O E_{i, j}=\beta_{0}+\beta_{1} \text { vaca }_{i, j}+\beta_{2} \text { vahu }_{i, j}+\beta_{3} s t v a_{i, j}+\beta_{4} \text { rcva }_{i, j}+\beta_{5} \operatorname{lnta}_{i, j}+\varepsilon_{i, j} \text { (7) } \\
& R O E_{i, j}=\beta_{0}+\beta_{1} \text { vaca }_{i, j}+\beta_{2} \text { vahu }_{i, j}+\beta_{3} s t v a_{i, j}+\beta_{4} \text { rcva }_{i, j}+\varepsilon_{i, j} \\
& R O E_{i, j}=\beta_{0}+\beta_{1} \text { mvaic }_{i, j}+\varepsilon_{i, j}
\end{aligned}
$$

The models testing the relation between NPM ratio and intellectual capital are:

$$
\begin{aligned}
& N P M_{i, j}=\beta_{0}+\beta_{1} \text { vaca }_{i, j}+\beta_{2} v \operatorname{ahu}_{i, j}+\beta_{3} \text { stva }_{i, j}+\beta_{4} \operatorname{rcva}_{i, j}+\beta_{5} \operatorname{lnta}_{i, j}+\varepsilon_{i, j} \\
& N P M_{i, j}=\beta_{0}+\beta_{1} \text { vaca }_{i, j}+\beta_{2} \text { vahu }_{i, j}+\beta_{3} s t v a_{i, j}+\beta_{4} r c v a_{i, j}+\varepsilon_{i, j} \\
& N P M_{i, j}=\beta_{0}+\beta_{1} \text { mvaic }_{i, j}+\varepsilon_{i, j}
\end{aligned}
$$

In these models, dependent and independent variables and their notations are as follows:

$v \operatorname{cad}_{i, j}$ : Capital Employed Efficiency for the company " $j$ "in time " $t$ " $v_{a h u_{i, j}}$ : Human Employed Efficiency for the company “j”in time " $t$ " $s t v a_{i, j}$ : Structural Capital Efficiency for the company " $j$ " in time " $t$ " $r c v a_{i, j}$ : Relational Capital Efficiency for the company " $j$ "in time " $t$ " $\operatorname{lnt} a_{i, j}$ : Natural Logarithm of Assets for the company " $j$ "in time " $t$ " mvaic $_{i, j}$ : Intellectual Capital Efficiency for the company " $j$ "in time " $t$ " $\varepsilon_{i, j}$ : Disturbance term for the company " $j$ "in time " $t$ " $M B_{i, j}$ : Market to Book Ratio for the company " $j$ "in time " $t$ " $R O A_{i, j}$ : Return on Asset Ratio for the company " $j$ "in time " $t$ " $R O E_{i, j}$ : Return on Equity Ratio for the company " $j$ "in time " $t$ " $N P M_{i, j}$ : Net Profit Margin for the company " $j$ "in time " $t$ " 


\section{Analysis and results}

This section delivers the findings of the empirical work. It firstly adverts the descriptive statistics and analysis; secondly, it explains the regression analysis of the models with comments.

The results in descriptive statistics suggest that the average of M/B ratio is 2.048, which means less than half of companies' value $(0.42)$ is reflected in financial statements. The value of companies on investors' perception is more than 2 times higher than their book values of equity reported. During this period, the companies have had a considerable profit margin around $13 \%$ as well as fruitful returns to their shareholders with approximately $10 \%$ of ROE and ROA is found as $6.6 \%$. The descriptive statistics of independent variables suggest that, VACA with 0.26 reveals that value added is 26 percent of total capital employed. In this four-year period, the companies have created value which is equal to their capital employed. Secondly, VAHU, for employee productivity is about 3.42, this means the share of employees in value added is less than one third. This is expected in production companies, for they are more capital intensive organizations.

\section{Table 1. Summary statistics of variables}

\begin{tabular}{lccccc}
\hline Variable & Obs. & Mean & Std. Dev. & Min & Max \\
\hline M/B & 196 & 2.0481 & 1.4338 & 0.36 & 9.29 \\
ROA & 196 & 0.0656 & 0.0861 & -0.22 & 0.36 \\
ROE & 196 & 0.1015 & 0.1952 & -1.01 & 0.60 \\
NPM & 196 & 0.1331 & 0.6771 & -0.42 & 8.92 \\
VACA & 196 & 0.2620 & 0.1283 & 0.01 & 0.70 \\
VAHU & 196 & 3.4163 & 2.0784 & 0.12 & 15.92 \\
STVA & 196 & 0.4763 & 1.0418 & -7.72 & 0.94 \\
RCVA & 196 & 0.3845 & 0.6751 & 0.03 & 8.83 \\
M-VAIC & 196 & 4.5392 & 2.4686 & -6.00 & 17.29 \\
LNTA & 196 & 20.8462 & 1.4222 & 17.68 & 23.83 \\
\hline
\end{tabular}

Table 2. Correlation among dependent and independent variables

\begin{tabular}{|c|c|c|c|c|c|c|c|c|c|c|}
\hline & $M / B$ & $R O A$ & ROE & NPM & VACA & VAHU & STVA & RCVA & MVAIC & LNTA \\
\hline$\overline{M B}$ & 1.000 & & & & & & & & & \\
\hline ROA & 0.138 & 1.000 & & & & & & & & \\
\hline ROE & $0.174 *$ & $0.873^{*}$ & 1.000 & & & & & & & \\
\hline NPM & -0.074 & $0.201 *$ & $0.158^{*}$ & 1.000 & & & & & & \\
\hline VACA & $0.213^{*}$ & $0.240^{*}$ & $0.221 *$ & $-0.151 *$ & 1.000 & & & & & \\
\hline VAHU & -0.053 & $0.378^{*}$ & $0.321 *$ & $k^{k} \quad-0.071$ & $0.170 *$ & 1.000 & & & & \\
\hline STVA & -0.036 & $0.311 *$ & $0.295^{*}$ & $-0.278^{*}$ & $0.361 *$ & $0.372 *$ & 1.000 & & & \\
\hline RCVA & 0.100 & $-0.385^{*}$ & $-0.404 *$ & 0.042 & -0.087 & $-0.221 *$ & $-0.673 *$ & 1.000 & & \\
\hline MVAIC & -0.022 & $0.357^{*}$ & $0.296^{*}$ & $-0.174^{*}$ & $0.323 *$ & $0.947^{*}$ & $* 0.570 *$ & $-0.201 *$ & 1.000 & \\
\hline LNTA & $-0.147^{*}$ & 0.010 & $0.165^{*}$ & ${ }^{k}-0.0080$ & $-0.162 *$ & 0.128 & 0.129 & -0.081 & 0.132 & 1.000 \\
\hline
\end{tabular}


In correlation analysis in table 2 , the relationships among all variables are shown. Table 2 presents significant relations among independent variables. A strong linear relation between the independent variables in the same model may cause multicollinearity which may result in less accurate estimation results (Gujarati, 2004). We used VIF test for measuring multicollinearity among the variables and we excluded "MVAIC" variable from this test as this variable is a variable in a single regression model. The VIF tests portray that there is not a perfect or imperfect multicollinearity among variables since the VIF results are quite less than 4 . The results of VIF test is illustrated in Table 3 below.

Table 3. VIF Tests for Independent Variables

\begin{tabular}{lcc}
\hline Variables & $\begin{array}{c}\text { Correlation } \\
\text { coefficients }\end{array}$ & VIF Scores \\
\hline VAHU-VACA & 0.170 & 1.030 \\
STVA-VACA & 0.361 & 1.150 \\
LNTA-VACA & -0.162 & 1.027 \\
STVA-VAHU & 0.372 & 1.161 \\
RCVA-VAHU & -0.221 & 1.051 \\
RCVA-STVA & -0.673 & 1.828 \\
\hline
\end{tabular}

The correlations among variables show that the relation between $M / B$ ratio and VACA is significant, reflecting that market promotes physical capital employed in the companies. ROA and ROE are significantly positively related with all independent variables. This significant relation between the explanatory variables and ROA and ROE is parallel to the findings of regression results which bear the highest overall significance and R2. On the other hand, NPM is only inversely correlated with capital employed and structural capital variables. The negative relation between NPM and these independent variables may result from the fact that; asset size with a high proportion of PP\&E has a positive effect on sales which is the denominator of this ratio.

\subsection{Regression Results}

In regression analysis we tested the relation between intellectual capital components and firms' market value and financial performance with some proxies. As a proxy for market value, $M / B$ ratio is used. We firstly regressed it with M-VAIC and secondly with a four factor model including VACA, VAHU, STVA and RCVA. In the third model, we added one more variable to the second model (LNTA) for controlling the variations caused by different asset sizes among companies. Subsequently, the dependency of company's performance to intellectual capital is tested. As indicator of performance, ROE, ROA, and NPM are used as proxies; and these financial indicators have been tested for the response to the models aforementioned in those of market value. The regression results are presented in Table 4 in the following. 
Ilker YILMAZ \& Goksel ACAR

Table 4. Regression Results for Models

\begin{tabular}{|c|c|c|c|c|c|c|c|c|c|}
\hline Models & VACA & VAHU & STVA & RCVA & LNTA & M-VAIC & $\beta_{0}$ & $\begin{array}{l}\text { Overall } \\
\text { Sig. }\end{array}$ & $\begin{array}{c}\text { Adjusted } \\
\mathbf{R}^{2}\end{array}$ \\
\hline Model & 3.5555 & -0.0267 & 0.0033 & 0.3866 & 0.0514 & \multirow[b]{2}{*}{--} & -0.0138 & \multirow{2}{*}{$23.99 * * *$} & \multirow{2}{*}{0.02} \\
\hline 1 & $3.42 * * *$ & -0.43 & 0.03 & $2.28 * *$ & 0.42 & & -0.01 & & \\
\hline Model & 3.4545 & -0.0242 & 0.0070 & 0.3873 & \multirow[b]{2}{*}{--} & \multirow{2}{*}{---} & 1.0734 & \multirow{2}{*}{$23.71 * * *$} & \multirow{2}{*}{0.04} \\
\hline 2 & $3.41 * * *$ & -0.40 & 0.05 & $2.29 * *$ & & & $3.36 * * *$ & & \\
\hline $\begin{array}{c}\text { Model } \\
3\end{array}$ & --- & --- & --- & --- & --- & $\begin{array}{c}0.0498 \\
1.07\end{array}$ & $\begin{array}{c}1.8218 \\
6.50 * * *\end{array}$ & 1.14 & 0.00 \\
\hline Model & 0.1888 & 0.0154 & 0.0082 & -0.0046 & 0.0024 & \multirow[b]{2}{*}{---} & -0.0881 & \multirow{2}{*}{$65.39 * * *$} & \multirow{2}{*}{0.17} \\
\hline 4 & $3.20 * * *$ & $4.39 * * *$ & 1.01 & -0.43 & 0.38 & & -0.67 & & \\
\hline Model & 0.1821 & 0.0155 & 0.0080 & -0.0054 & \multirow[b]{2}{*}{--} & \multirow{2}{*}{--- } & -0.0369 & \multirow{2}{*}{$65.01 * * *$} & \multirow{2}{*}{0.18} \\
\hline 5 & $3.19 * * *$ & $4.49 * * *$ & 0.99 & -0.51 & & & $-2.05^{* *}$ & & \\
\hline Model & \multirow{2}{*}{---} & \multirow{2}{*}{--- } & \multirow{2}{*}{--- } & \multirow{2}{*}{---} & \multirow{2}{*}{--- } & 0.0204 & -0.0268 & \multirow{2}{*}{$54.39 * * *$} & \multirow{2}{*}{0.12} \\
\hline 6 & & & & & & $7.38 * * *$ & $-1.67^{*}$ & & \\
\hline Model & 0.3194 & 0.0256 & -0.001 & -0.208 & 0.0244 & \multirow[b]{2}{*}{--} & -0.5688 & \multirow{2}{*}{$35.07 * * *$} & \multirow{2}{*}{0.17} \\
\hline 7 & $2.45^{* *}$ & $3.30 * * *$ & -0.07 & -0.86 & $1.86^{*}$ & & $-2.03 * *$ & & \\
\hline Model & 0.2673 & 0.0272 & 0.0033 & -0.0170 & \multirow[b]{2}{*}{--- } & $-H$ & -0.0565 & & \\
\hline 8 & $2.08 * *$ & $3.50 * * *$ & 0.18 & -0.7 & & -- & -1.40 & $31.16+\pi$ & 0.15 \\
\hline Model & 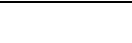 & 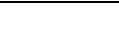 & - & 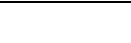 & 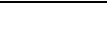 & 0.0320 & -0.0439 & & 0 \\
\hline 9 & --- & --- & --- & -- & --- & $5.17 * * *$ & -1.20 & & 8 \\
\hline Model & -0.0323 & 0.0145 & -0.3091 & -0.2679 & 0.0120 & & 0.0919 & & \\
\hline 10 & -0.08 & 0.06 & $-4.48 * * *$ & $-2.82 * * *$ & 0.36 & --- & 0.13 & $25.60^{* * *}$ & 0.09 \\
\hline Model & -0.0666 & 0.0154 & -0.3052 & -0.2659 & & & 0.3457 & & 10 \\
\hline 11 & -0.17 & 0.65 & $4.49 * * *$ & $-2.81 * * *$ & & & $2.66 * * *$ & . & .10 \\
\hline Model & -- & -- & --- & & & -0.0288 & 0.2636 & 160 & רחم \\
\hline 12 & -- & -- & -- & - & --- & -1.27 & $2.21 * *$ & 1.60 & 0.02 \\
\hline
\end{tabular}

The first three models handle the relation between $M / B$ ratio and $I C$ components. Model 1 consists of four IC components (VACA, VAHU, STVA, RCVA) and a controlling variable for assets (LNTA). The analysis reveals that physical capital efficiency (VACA) and relational capital efficiency (RCVA) have significant positive impact on M/B ratio, however human capital efficiency (VAHU) and structural capital efficiency (STVA) does not have any significant effect on it. The controlling variable for assets (LNTA) also lacks significance on the dependent variable. The model has overall significance but its power to explain the total variation in $M / B$ ratio is poor with about $2 \%$. Model 2 has four IC components only and LNTA is excluded in this model. Model 2 demonstrates strong similarities with the preceding model. The significant and insignificant variables as well as the overall significance are very close in models 1 and 2 however, model 2 has a higher $R^{2}$ value and intercept in Model 1 was insignificant and negative whereas, Model 2 has a positive and significant intercept. This results from the inclusion of LNTA variable in first model. Model 3 is designed to see the effect of one factor (M-VAIC) on M/B ratio. According to tests, M-VAIC has not a significant influence on dependent 
variable, and the model does not have overall significance and its explanatory power is almost zero.

These results suggest that investors are eager to pay more for physical capital and they are also interested in with relational capital of companies. The human capital and structural capital are less attractive for market. We can also deduct that the asset controlling variable has not a significant effect on these three models.

The models for analyzing the effect of IC components on ROA have the same steps with those of $\mathrm{M} / \mathrm{B}$ ratio. In Model 4, like in Model 1, four IC components along with LNTA have been tested for the effects on ROA. The variables of physical capital (VACA) and human capital (VAHU) have a significant positive effect on ROA, the other components and intercept are not significant. The model has overall significance and $\mathrm{R}^{2}$ is about $17 \%$, which can be considered a high goodness of fit for such models. Model 5 is four-variable model and it has almost same results with Model 4. The significance levels, $R^{2}(18 \%)$ and even the coefficients are almost equal. Model 6 handling ROA is one factor model. The independent variable in this model affects significantly the ROA and model has overall significance and moderate $R^{2}(12 \%)$. These results reveal that ROA is strongly affected by physical capital and human employment. Other components are not significant. This is a typical situation as ROA measures the efficiency of assets in generating profit. The changes in efficiency of physical assets and employee productivity will be effective on revenues and, in turn they will influence income.

As the third dependent variable, ROE is included into the analysis. Model 7, Model 8 , and Model 9 portray the regression results regarding ROE and IC components. Model 7 outlines the exposition of ROE to five factors. The results show that ROE is significantly affected by VACA, VAHU, and LNTA. Remarkably, control variable for assets has a power on ROE at $10 \%$ significance level. It may be caused from the fact that with the increase of assets the economies of scale and efficiency increases. This will affect income positively. However, equity may not necessarily increase at the same manner. This will result in an increase in ROE.

The model has a strong significance and explanatory power (17\%). Model 8 which includes 4 factors is contributing to the findings of previous model. In Model 8 , physical capital and human capital productivities considerably affects ROE. On the other hand, despite satisfactory significance level and $R^{2}(15 \%)$, they are significantly lower than those of Model 7, resulting from the exclusion of a significant variable, namely LNTA. Intercept also lacks significance in Model 8. Model 9 is the one factor model in which M-VAIC has a strong impact on ROE, yet overall significance and $\mathrm{R}^{2}(8 \%)$ are not as high as the former models of ROE.

The last three models take net profit margin (NPM) as dependent variable. Model 10 with five factor model has STVA and RCVA as significant variables with negative signs. The inverse relation between STVA and NPM may be related with the calculation of STVA. As mentioned in previous section, STVA is calculated as the 
division of Structural Capital to Value Added. On the other hand, Value Added has a positive relation with NPM. Thus, the increase in Value Added infer to a relative decrease in STVA. The relation among RCVA and NPM is also similar in a way that, RCVA is calculated as the total of advertising and marketing expenses, which has a negative effect on net profit. The results show no significance for VACA, VAHU and LNTA. Though the model catches overall significance, the $R^{2}$ is relatively lower than ROA and ROE models with five factors. Model 11 produces the similar results with Model 10. The only difference is the significance of intercept. As the asset control variable is excluded from the model, the weight of intercept increases and intercept becomes significant. Overall significance and $R^{2}$ are also same. Model 12 having a single variable has deficiency in explaining the variation of NPM, because of lower $\mathrm{R}^{2}$ insignificant variable (M-VAIC), as well as lacking overall significance.

\section{Conclusion}

This study examined how intellectual capital affects value and performance in Turkish listed production companies in BIST 100 Index. We selected four dependent variables; M/B for market value, and ROA, ROE and NPM for financial performance. Then we applied three models for each of these dependent variables. Firstly, a five factor models with variables of VACA, VAHU, STVA, RCVA, and LNTA have been used. The second model includes VACA, VAHU, STVA, and RCVA. In the third model only M-VAIC, which is the total of VACA, VAHU, STVA and RCVA, is analyzed. In total we had twelve models for four regressands.

Firstly, M/B ratio is used for evaluating the market value of companies, and the models with multi-factor components present better results in understanding market value. The magnitude of assets is not relevant in investors' eye because the asset control variable is insignificant. Additionally, despite their significance, the models have poor power of goodness of fit to explain the changes in M/B ratio. The underlying reason for this issue comes from complexity of decision making processes of traders in stock markets. They not only rely on company financial information, but they also use many other information such as general economic condition, industrial issues, interest rate, foreign exchanges and etc. Besides, investors put physical and relational capital forward in their decisions, because these two variables have positive and significant effect on $M / B$ ratio.

Secondly, the study aimed to analyze whether variations of financial performance is due to intellectual capital. For this purpose, we selected three different indicators for financial performance, namely; ROA, ROE, and NPM as dependent variables and tried to understand to what extent they are affected from intellectual capital. For each of these performance indicators we constructed three M-VAIC models, which were similar to those of M/B Ratio.

As one of the major performance indicator, ROA is significantly affected by capital employed and human capital, whereas structural capital, relational capital, and magnitude of assets does not have a significant effect on ROA. Alternatively, one 
factor model has provided significant results for ROA. Generally speaking, the power of models in explaining ROA and ROE is stronger than others. This may result from the fact that both ROA and ROE variables are strongly related with balance sheet and income statement like independent variables. In addition, VACA and VAHU are efficiency measures for physical capital and human capital, and ROA is asset efficiency, and it is an expected result that they are significantly related.

The results of ROE are parallel with ROA with a difference that magnitude of assets is significant in estimating ROE. This means that the ROE is changing depending on the variation in assets and they have positive relation. The models, however, are not as strong as previous models in estimating the last performance indicator, NPM. The models for NPM have lower overall significances as well as they bear lower $\mathrm{R}^{2}$ values. On the contrary, to previous findings, NPM is strongly related to structural capital and relational capital in inverse direction. The main reason for this is that these two variables are computed over expenses which have a negative effect on profit.

Empirical results show that multi factor models are better explaining the effects of intellectual capital on company's value and performance. In all of the tests coefficients of these models have more significance, and overall significance scores are comparably higher in these models.

As an indicator of performance ROA or ROE has more accuracy and dependency, so these variables can be selected over NPM. NPM is a measure derived from the items of income statement. However, ROA and ROE are both linked to balance sheet and income statement; this may cause them to be more sensitive and related to intellectual capital factors, which are derived from both income statement and balance sheet.

According to the results, amongst the components of multiple factors model, the most influential explanatory variable was capital employed, then comes human capital, and relational capital. Structural capital has the lowest effect on explaining both company's value and performance.

The results of the study have important implications for managers. Although physical capital is important for sustainability and long-term profitability, intellectual capital has also a value-enhancing potential.

\section{References}

Belkaoui, A.R. (2003). Intellectual capital and firm performance of US multinational firms: A study of the resource- based and stakeholder views. Journal of Intellectual Capital 4(2), 215226. https://doi.org/10.1108/14691930310472839

Bontis, N. (1998). Intellectual capital: an exploratory study that develops measures and models. Management Decision 36(2), 63-76. https://doi.org/10.1108/00251749810204142 
Bontis, N. (1999). Managing organizational knowledge by diagnosing intellectual capital: framing and advancing the state of the field. International Journal of Technology Management 18(5-8), 433-62. http://dx.doi.org/10.1504/IJTM.1999.002780

Bontis, N., Keow, W.C.C. and Richardson, S. (2000). Intellectual capital and business performance in Malaysian industries. Journal of Intellectual Capital 1(1), 85-100. https://doi.org/10.1108/14691930010324188

Bornemann, M., Knapp, A., Schneider, U. and Sixl, K.I. (1999). Holistic measurement of intellectual capital. International Symposium: Measuring and Reporting Intellectual Capital: Experiences, Issues and Prospects, available at http://www.oecd.org/industry/ind/1947871.pdf (accessed 25.03.2017)

Bozbura, F.T. (2004). Measurement and application of intellectual capital in Turkey. The Learning Organization 11(4), 357-367. https://doi.org/10.1108/09696470410538251

Chen, M.C., Cheng, S.J. and Hwang, Y. (2005). An empirical investigation of the relationship between intellectual capital and firms' market value and financial performance. Journal of Intellectual Capital 6 (2), 159-176. https://doi.org/10.1108/14691930510592771

Edvinsson, L. (1997). Developing intellectual capital at Skandia. Long Range Planning 30(3), 366-73. https://doi.org/10.1016/S0024-6301(97)00016-2

Edvinsson, L. and Malone, M.S. (1997). Intellectual Capital: Realizing Your Company's True Value by Finding Its Hidden Brainpower. Harper Business, New York, NY.

Firer, S. and Williams, S.M. (2003). Intellectual capital and traditional measures of corporate $\begin{array}{llll}\text { performance. Journal of Intellectual Capital 4(3), 348-60. } & \end{array}$ https://doi.org/10.1108/14691930310487806

Gujarati, D. N.(2004). Basic Econometrics.4th edition. New Delhi Tata McGraw-Hill Publishing Company Limited

Guthrie, J. and Petty, R. (2000). Intellectual capital: Australian annual reporting practices. Journal of Intellectual Capital 1(3), 241-51. https://doi.org/10.1108/14691930010350800

lazzolino, G. and Laise, D. (2013). Value added intellectual coefficient (VAIC): a methodological and critical review. Journal of Intellectual Capital 14(4), 547-563. https://doi.org/10.1108/JIC-12-2012-0107

Klein, D.A. \& Prusak, L. (1994). Characterising Intellectual Capital. Ernst \& Young, Cambridge.

Lehtimäki, J. \& Lehtimäki, J.(2016). Impact of Knowledge Capital on Performance of Firms: A Case of Firms in Finland. Eurasian Journal of Business and Economics, 2016, 9 (18), 41-59. https://doi.org/10.17015/ejbe.2016.018.03

Maditinos, D., Šević, Z. \& Tsairidis, C. (2010). Intellectual capital and business performance: an empirical study for the Greek listed companies. European Research Studies Journal 13(3), 145-167. http://www.ersj.eu/repec/ers/papers/10 3 p7.pdf

Nazari, J.A. \& Herremans, I.M. (2007). Extended VAIC model: measuring intellectual capital Components. Journal of Intellectual Capital 8(4), 595-609. https://doi.org/10.1108/14691930710830774

Nimtrakoon,S. (2015). The relationship between intellectual capital, firms' market value and financial performance Empirical evidence from the ASEAN. Journal of Intellectual Capital, 16 (3), 587-618. https://doi.org/10.1108/JIC-09-2014-0104 
Ozkan, N., Cakan, S. \& Kayacan, M. (2017). Intellectual Capital and Financial Performance: A Study of the Turkish Banking Sector, Borsa Istanbul Review 17(3), 190-198 https://doi.org/10.1016/i.bir.2016.03.001.

Pulic, A. (2000). VAIC-an accounting tool for IC management. International Journal of Technology Management 20(5/6/7/8). http://dx.doi.org/10.1504/IJTM.2000.002891

Roos, J., Roos, G., Dragonetti, N.C. \& Edvinsson, L. (1997). Intellectual Capital: Navigating in the New Business Landscape, Macmillan, Basingstoke.

Sharabati, A.A.A., Naji Jawad, S. \& Bontis, N. (2010). Intellectual capital and business performance in the pharmaceutical sector of Jordan. Management Decision 48(1), 105-131. https://doi.org/10.1108/00251741011014481

Stahle, P., Stahle, S. \& Aho, S. (2011). Value added intellectual coefficient (VAIC): a critical analysis. Journal of Intellectual Capital 12(4), 531-551. https://doi.org/10.1108/14691931111181715

Stewart, T. (1997). Intellectual Capital: The New Wealth of Organizations, Doubleday /Currency, New York, NY.

Sveiby, K.E. (1997). The New Organizational Wealth: Managing and Measuring KnowledgeBased Assets, Berrett-Koehler, New York, NY.

Ulum, I., Ghozali, I. \& Purwanto, A. (2014). Intellectual capital performance of Indonesian banking sector: a modified VAIC (M-VAIC) perspective. Asian Journal of Finance \& Accounting 6(2), 103-123. https://doi.org/10.5296/ajfa.v6i2.5246

Ulum,I., Kharismawati,N. \& Syam,D. (2017).Modified value-added intellectual coefficient (MVAIC) and traditional financial performance of Indonesian biggest companies. International Journal of Learning and Intellectual Capital (IJLIC) 14(3). http://dx.doi.org/10.1504/IJLIC.2017.10006259

Yalama, A. \& Coskun, M. (2007). Intellectual capital performance of quoted banks on the Istanbul stock exchange market. Journal of Intellectual Capital 8(2), 256-271. https://doi.org/10.1108/14691930710742835

Zambon, S. (2002). Accounting, intangible and intellectual capital: an overview of the issues and some considerations. Working Paper 4, University of Ferrara, Ferrara.

Zeghal, D. \& Maaloul, A. (2010). Analysing Value Added as an Indicator of Intellectual Capital and its Consequences on Company performance. Journal of Intellectual Capital 11(1), 39-60. https://doi.org/10.1108/14691931011013325. 